\title{
Reliability Assessment of Photoelectric Smoke Detector, Ionization Smoke Detector and a Fire Alarm Control Panel with Both Detectors AS Notification Device
}

\author{
Anil Chandra, Surbhi Gupta, Chandra K Jaggi
}

\begin{abstract}
Notification device like smoke detectors are critical and important part of a Fire Alarm Control Panel (FACP). Popularly used smoke alarms in commercial establishments in India are photoelectric smoke alarms (PESD) and ionization smoke alarms (ISD). In this study reliability assessments of PESD with Integrated Circuit (IC) - MC145010 and ISD with IC MC145017 have been carried out on the basis of reliabilities of their respective electronic components. The cases considered are: (I) Failure rates of all components are equal and constant over time (II) Failure rates of all components are equal and follow Weibull distribution and (III) Failure rates of all components are different. To determine failure rates of 9 volt battery of both detectors additional assumptions taken are, (a) battery life is 10 years with constant failure rate, (b) battery life follows Weibull distribution. In this paper the reliability and failure rate of two types of smoke alarms have been calculated based on failure rates of their electronic parts like resistors, capacitors, Integrated Circuits etc. These failure rates have been subsequently used for reliability assessment of a non-addressable FACP containing four PESDs and four ISDs as notification device. A comparison of failure rates was also performed on the basis of two quality factors of electronic components - military specific and lower than military specific.
\end{abstract}

Mean Time To Failure (MTTF) of PESD and ISD have been calculated in all the cases. Subsequently, MTTF values obtained in case III were used to approximate failure rates for case I case II.

Keywords: Photoelectric smoke detector, Ionization smoke detector, Reliability, MTTF

\section{INTRODUCTION}

Fire results in loss of life and money. The loss becomes immense when fire breaks out in a critical facility like nuclear establishment. The Fire Alarm System is very important in giving timely warning which enables us to keep the fire in control or in timely evacuation of the facility to minimize loss

Revised Manuscript Received on December 30, 2019.

* Correspondence Author

Anil Chandra, Amity Institute of Applied Sciences, Amity University Uttar Pradesh, Sector 125, NOIDA,U.P. India (e-mail: achandra@amity.edu).

Dr. Surbhi Gupta, Amity Institute of Applied Sciences, Amity University Uttar Pradesh, Sector 125, NOIDA, U.P. India (e-mail: sgupta11@amity.edu).

Prof. (Dr.) Chandra K Jaggi , Department of Operational Research, University of Delhi, Delhi 110007 (e-mail: ckjaggi@yahoo.com)

(C) The Authors. Published by Blue Eyes Intelligence Engineering and Sciences Publication (BEIESP). This is an open access article under the CC BY-NC-ND license (http://creativecommons.org/licenses/by-nc-nd/4.0/) of life. Considering the importance of a fire alarm system, its reliability becomes equally important. One of the important approaches adopted to determine reliability of fire alarm system is by analyzing the failure rate data of its components like heat detectors, smoke detectors, water sprinklers etc. However, in order to get a better estimation, it is equally important to have a large sample size of failure rate data which has been one of the limitations in this approach [1]. In past reliability assessment of systems, like water sprinkler [2] and fire alarm system[3], has been carried out by taking failure rates of its various components using resources like OREDA [4] handbook. While determining reliability of fire alarm systems another limitation happens to be unavailability of reliability data of electronic components due to their higher reliability as pointed out by researchers while analyzing the data of fire protection features pertaining to German nuclear power plants [5]. [9] predict reliability of new improved current source whereas [10] study on the reliability evaluation of electric vehicle charging system. Authors in this paper considered a fire alarm system consists of notification device - like heat alarm, smoke alarm, which are connected to a Fire Alarm Control Panel (FACP). The warning system - like flashing LED, alarm are also connected to FACP which in turn activates the fire control device (water sprinkler, door closers etc.) in alarm state. The failure rates of these electronic parts are determined by using methodology given in MIL-HDBK-217 F [6]. These failure rates are then used for reliability assessment of fire alarm control panel to which these smoke alarms are connected. Initially, the failure rate, Reliability and Mean Time to Failure (MTTF) of the two smoke detectors are calculated. Subsequently, these results have been used to calculate the failure rate, Reliability and MTTF of the FACP. The two quality factors of components - "Military Specific" (MIL) and "Lower than Military Specific" (LOW), as per MIL-HDBKK-217F, were also used for assessing difference between failure rates of PESD, ISD and FACP.

\section{SYSTEM DESCRIPTION}

The most popular smoke detectors used nowadays in Fire Alarm Systems are photoelectric smoke detector (PESD) and Ionization smoke detector (ISD). Dual smoke alarm system uses these two technologies in one detector.

PESD is more responsive to smoldering fires while ISD is more responsive to invisible smoke produced by fast flaming fires. These detectors are important part of the fire protection system.

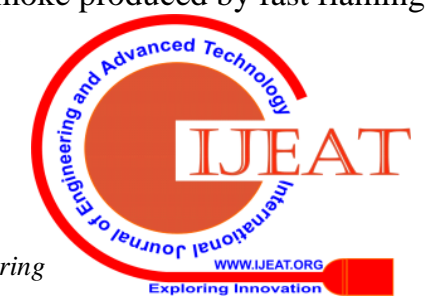




\section{Reliability Assessment of Photoelectric Smoke Detector, Ionization Smoke Detector and a Fire Alarm Control Panel with Both Detectors AS Notification Device}

The system model discussed in this paper contains a non-addressable Fire Alarm Control Panel (FACP) of a particular zone in which the notification devices connected are smoke detectors (PESD and ISD). A non-addressable fire alarm system is the one which only tells us a zone of possible fire breakout while an addressable fire alarm system tells us exact location of the detector which is in alarm state. Since, installation and maintenance of addressable fire alarm system is expensive as compared to a non-addressable fire alarm system, the commercial establishments in India prefer to use the latter.

\section{Photoelectric SMoke Detector (PESD)}

PESD contains an infrared (IR) light emitter and IR detector located at two ends of the detection chamber in such a way that the light beams from IR emitter do not reach the IR detector. When smoke enters the chamber these light beams are scattered and some of which reaches the IR detector thereby putting the circuit in alarm state [12]. The system configuration and component details are given in Fig. 1 and Table I respectively.

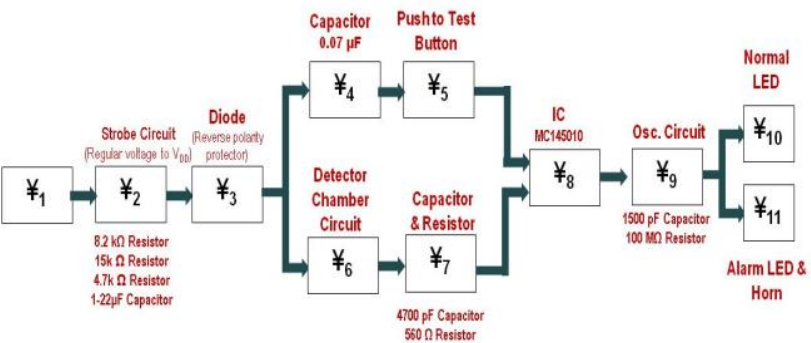

Fig. 1. System Configuration - PESD.

TABLE I

DETAILS OF COMPONENTS - PESD

\begin{tabular}{|c|c|c|c|c|}
\hline State & $\begin{array}{l}\text { Component } \\
\text { Name }\end{array}$ & $\begin{array}{l}\text { Hardware } \\
\text { Details }\end{array}$ & Function & $\begin{array}{l}\text { Failures } / 10^{6} \\
\text { Hours }\end{array}$ \\
\hline$¥_{1}$ & $\begin{array}{l}9 \text { 9-volt } \\
\text { Battery }\end{array}$ & $\begin{array}{l}\text { Lithium } \\
\text { Manganese } \\
\text { Dioxide Battery }\end{array}$ & $\begin{array}{l}\text { Powers the } \\
\text { circuit }\end{array}$ & $\begin{array}{l}11.42 \\
\text { [Battery life } \\
=10 \text { years, } \\
\text { exponential } \\
\text { failure rate ] } \\
0.303 t \\
\text { (Weibull } \\
\text { failure rate) }\end{array}$ \\
\hline$¥_{2}$ & $\begin{array}{l}\text { Strobe } \\
\text { Circuit }\end{array}$ & $\begin{array}{l}\text { 8.2k resistor, } \\
15 \mathrm{k} \text { resistor, } \\
4.7 \mathrm{k} \text { resistor } \\
\text { variable } \\
\text { capacitor (1 to } \\
22 \mu \mathrm{F} \text { ) }\end{array}$ & $\begin{array}{l}\text { Regulates } \\
\text { voltage in } \\
\text { circuit }\end{array}$ & 0.762 \\
\hline$¥_{3}$ & Diode & $\begin{array}{l}\text { Reverse } \\
\text { polarity } \\
\text { protection } \\
\text { diode }\end{array}$ & $\begin{array}{l}\text { Reverse } \\
\text { polarity } \\
\text { protection }\end{array}$ & 0.134 \\
\hline$¥_{4}$ & Capacitor & $\begin{array}{ll}0.07 & \mu \mathrm{F} \\
\text { capacitor } & \end{array}$ & $\begin{array}{l}\text { Regulates } \\
\text { gain settings } \\
\text { for Push To } \\
\text { Test (PTT) } \\
\text { Switch }\end{array}$ & 0.036 \\
\hline$¥_{5}$ & PTT Switch & $\begin{array}{l}\text { Push to Test } \\
\text { Switch (PTT) }\end{array}$ & $\begin{array}{l}\text { Test } \\
\text { circuit }\end{array}$ & 0.12 \\
\hline$¥_{6}$ & $\begin{array}{l}\text { Detection } \\
\text { Chamber } \\
\text { Circuit }\end{array}$ & $\begin{array}{l}\text { IR detector, IR } \\
\text { emitter, } 250 \mathrm{k} \\
\text { resistor, } \quad 1 \mathrm{k} \\
\text { resistor, a } \\
\text { variable resistor } \\
\text { (4.7 to } 22 \mathrm{k}) \text {, } \\
\text { NPN transistor } \\
\text { and } 100 \mu \mathrm{F}\end{array}$ & $\begin{array}{l}\text { To detect } \\
\text { presence of } \\
\text { smoke }\end{array}$ & 1.968 \\
\hline
\end{tabular}

\begin{tabular}{|c|c|c|c|c|}
\hline & & capacitor & & \\
\hline$¥_{7}$ & $\begin{array}{l}\text { Capacitor \& } \\
\text { Resistor }\end{array}$ & $\begin{array}{l}4700 \quad \mathrm{pF} \\
\text { capacitor and } \\
560 \Omega \text { resistor }\end{array}$ & $\begin{array}{l}\text { Determines } \\
\text { the gain on } \\
\text { the detector } \\
\text { except during } \\
\text { PTT }\end{array}$ & 0.061 \\
\hline$¥_{8}$ & $\begin{array}{l}\text { Integrated } \\
\text { Circuit }\end{array}$ & $\begin{array}{l}\text { IC } \\
\text { MC145010 }\end{array}$ & $\begin{array}{l}\text { Activates } \\
\text { alarm or } \\
\text { keeps circuit } \\
\text { in non-alarm } \\
\text { state }\end{array}$ & 0.112 \\
\hline$¥_{9}$ & $\begin{array}{l}\text { Oscillating } \\
\text { Circuit }\end{array}$ & $\begin{array}{l}100 \mathrm{M} \Omega \text { resistor } \\
\text { and } 1500 \mathrm{pF} \\
\text { capacitor }\end{array}$ & $\begin{array}{l}\text { Oscillates to } \\
\text { alarm or non } \\
\text { alarm state as } \\
\text { per output } \\
\text { provided by } \\
\text { IC }\end{array}$ & 0.111 \\
\hline$¥_{10}$ & $\begin{array}{l}\text { Normal } \\
\text { LED }\end{array}$ & LED & $\begin{array}{l}\text { Indicates no } \\
\text { fire }\end{array}$ & 0.033 \\
\hline$¥_{11}$ & $\begin{array}{l}\text { Alarm LED } \\
\text { \& Horn }\end{array}$ & LED \& Horn & Indicates fire & 2.533 \\
\hline
\end{tabular}

Ionization Smoke Detector (ISD)

ISD, contains a radioactive element at safe level that ionizes the air inside detection chamber, thus producing a small and constant electric current to flow in the chamber. When smoke enters the chamber, this flow is disturbed thereby disturbing the balance of the current. This disturbance is detected by the circuit thereby resulting it to be switched to alarm state[17]. The system configuration and component details are given in Fig. 2 and Table II respectively.

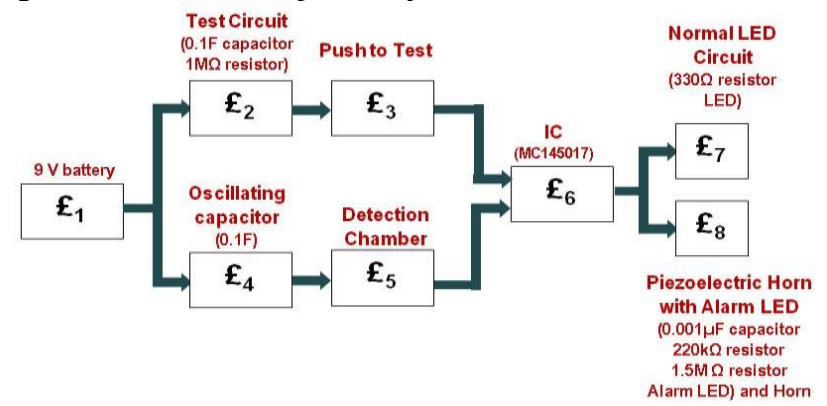

Fig. 2. System Configuration - ISD.

TABLE II Details of components - ISD

\begin{tabular}{|c|c|c|c|c|}
\hline $\begin{array}{c}\text { Stat } \\
\text { e }\end{array}$ & $\begin{array}{c}\text { Component } \\
\text { Name }\end{array}$ & $\begin{array}{l}\text { Hardware } \\
\text { Details }\end{array}$ & Function & $\begin{array}{l}\text { Failures } / 10^{6} \\
\text { Hours } \\
\text { [Source] }\end{array}$ \\
\hline$£_{1}$ & $\begin{array}{l}\text { 9-volt } \\
\text { Battery }\end{array}$ & $\begin{array}{l}\text { Lithium } \\
\text { Manganese } \\
\text { Dioxide } \\
\text { Battery }\end{array}$ & $\begin{array}{l}\text { Powers the } \\
\text { circuit }\end{array}$ & $\begin{array}{l}11.42 \text { [Battery } \\
\text { life assumed to } \\
\text { be } 10 \text { years } \\
\text { exponential } \\
\text { failure rate] } \\
0.303 t \\
\text { (Weibull } \\
\text { failure rate) }\end{array}$ \\
\hline$£_{2}$ & Test Circuit & $\begin{array}{l}0.1 \mu \mathrm{F} \\
\text { capacitor and } \\
1 \mathrm{M} \Omega \text { resistor }\end{array}$ & $\begin{array}{l}\text { Regulates gain } \\
\text { settings for PTT }\end{array}$ & 0.089 \\
\hline$£_{3}$ & PTT Switch & $\begin{array}{l}\text { Push to Test } \\
\text { (PTT) Switch }\end{array}$ & Tests the Circuit & 0.12 \\
\hline$£_{4}$ & $\begin{array}{l}\text { Oscillating } \\
\text { Capacitor }\end{array}$ & $\begin{array}{l}0.1 \mu \mathrm{F} \\
\text { Capacitor }\end{array}$ & $\begin{array}{l}\text { Together with IC } \\
\text { it operates with a } \\
\text { period of } \\
\text { approx. } 1 \text { second } \\
\text { and checks for } \\
\text { any change in } \\
\text { electric current } \\
\text { of detection } \\
\text { chamber }\end{array}$ & 0.036 \\
\hline
\end{tabular}




\begin{tabular}{|c|c|c|c|c|}
\hline$\varepsilon_{5}$ & $\begin{array}{l}\text { Detection } \\
\text { Chamber }\end{array}$ & $\begin{array}{l}\text { Contains } \\
\text { radioactive } \\
\text { element } \\
\text { Americium } \\
8.2 \quad \mathrm{M} \Omega \\
\text { resistor } \\
\end{array}$ & $\begin{array}{lr}\text { To } & \text { detect } \\
\text { presence } & \text { of } \\
\text { smoke } & \\
\end{array}$ & 0.127 \\
\hline$\varepsilon_{6}$ & $\begin{array}{l}\text { Integrated } \\
\text { Circuit }\end{array}$ & $\begin{array}{l}\text { IC } \\
\text { MC145017 }\end{array}$ & $\begin{array}{l}\text { Activates the } \\
\text { alarm when PTT } \\
\text { is activated or } \\
\text { when detection } \\
\text { chamber circuit } \\
\text { detects smoke, } \\
\text { otherwise keeps } \\
\text { the detector in } \\
\text { normal state }\end{array}$ & 0.112 \\
\hline$\sum_{7}$ & $\begin{array}{l}\text { Normal } \\
\text { LED Circuit }\end{array}$ & $\begin{array}{l}330 \Omega \text { resistor } \\
\text { and LED }\end{array}$ & Indicates no fire & 0.066 \\
\hline$£_{8}$ & $\begin{array}{l}\text { Horn Circuit } \\
\text { with Alarm } \\
\text { LED }\end{array}$ & $\begin{array}{l}0.001 \mu \mathrm{F} \\
\text { capacitor, } \\
220 \mathrm{k} \Omega \text {, } 1.5 \\
\mathrm{M} \Omega \text { resistors, } \\
\mathrm{LED} \quad \text { and } \\
\text { Horn }\end{array}$ & Indicates Fire & 2.65 \\
\hline
\end{tabular}

Non AdDressable Fire Alarm Control PANEL (FACP)

The System configuration and details of components are given in Figure 3 and Table III respectively.

\section{Non AdDressable Fire Alarm Control PANEL (FACP)}

The System configuration and details of components are given in Figure 3 and Table III respectively.

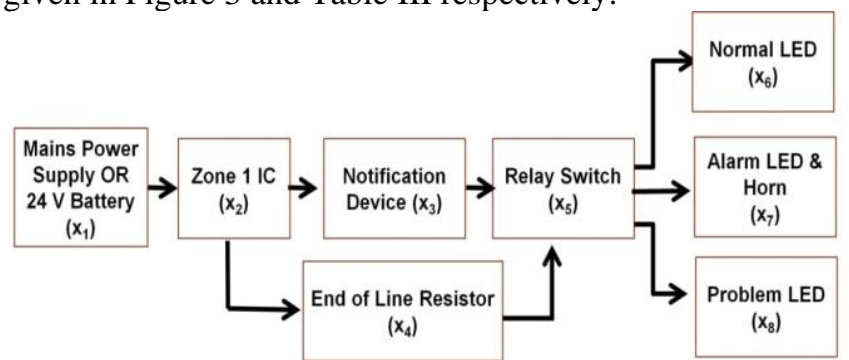

Fig. 3 system Configuration - FACP

TABLE III

DETAILS OF COMPONENTS - FACP

\begin{tabular}{|c|c|c|c|c|}
\hline State & $\begin{array}{l}\text { Component } \\
\text { Name }\end{array}$ & $\begin{array}{l}\text { Hardware } \\
\text { Details }\end{array}$ & Function & $\begin{array}{l}\text { Failures/10 } \\
\text { Hours }\end{array}$ \\
\hline $\mathrm{x}_{1}$ & $\begin{array}{l}\text { Mains } \\
\text { Power } \\
\text { Supply or } \\
\text { 24-V Battery }\end{array}$ & $\begin{array}{l}\text { Mains } \\
\text { Power } \\
\text { Supply and } \\
24-\mathrm{V} \\
\text { Battery }\end{array}$ & $\begin{array}{l}\text { Mains Power } \\
\text { Supply Powers the } \\
\text { FACP } \\
\text { Battery Backup in } \\
\text { case power supply } \\
\text { trips }\end{array}$ & 0 \\
\hline $\mathrm{X}_{2}$ & Zone 1 IC & $\begin{array}{l}\text { Integrated } \\
\text { Circuit }\end{array}$ & $\begin{array}{l}\text { Checks } \\
\text { notification } \\
\text { device whether in } \\
\text { normal state or } \\
\text { alarm state or } \\
\text { some problem in } \\
\text { the connection }\end{array}$ & 0.131 \\
\hline $\mathrm{X}_{3}$ & $\begin{array}{l}\text { Notification } \\
\text { Device }\end{array}$ & $\begin{array}{l}4 \mathrm{PESD} \\
4 \mathrm{ISD}\end{array}$ & $\begin{array}{l}\text { Notifies the FACP } \\
\text { in case of Fire }\end{array}$ & $\begin{array}{l}98.64 \\
10.05 \\
13.75 \\
\text { (Table II } \\
\text { Table IV) } \\
\end{array}$ \\
\hline $\mathrm{x}_{4}$ & $\begin{array}{l}\text { End of Line } \\
\text { Resistor } \\
\text { (EoLR) }\end{array}$ & $\begin{array}{l}\text { Resistor } \\
4.7 \mathrm{k} \Omega\end{array}$ & $\begin{array}{l}\text { Checks the circuit } \\
\text { for any problem in } \\
\text { notification } \\
\text { device }\end{array}$ & 0.033 \\
\hline $\mathrm{X}_{5}$ & $\begin{array}{l}\text { Relay } \\
\text { Switch }\end{array}$ & $\begin{array}{l}\text { Relay } \\
\text { Switch }\end{array}$ & $\begin{array}{ll}\text { Remains } & \text { in } \\
\text { "Normal" State if } \\
\text { no smoke is } \\
\text { detected } \\
\text { notification }\end{array}$ & 6 \\
\hline
\end{tabular}

A. General Assumptions:

I. Full working efficiency of each component during initial stage

II.Component states being either good or fail with no repair facility available

III. Statistical independence of failure rates

IV. Arbitrary failure time of all components

V.Supply between any two components of the system being fully reliable

B. Additional assumptions when MILHDBK-217F methodology was adopted

VI. The environment conditions were taken as ground fixed (Moderately controlled environment with adequate cooling) VII. The failure rates of components is constant with time, unless specified otherwise

VIII.The quality factor of hardware was assumed to be lower than military specifications, unless specific otherwise

\section{METHOD OF RELIABILITY ESTIMATION}

As per the methodology presented in [6] for most electronic components (like resistors, capacitors, switches, LEDs etc.) the failure rate value is calculated by:

$$
\lambda=\lambda_{B} \pi_{1} \pi_{2} \pi_{3} \pi_{4} \ldots \pi_{n} \text { Failures per } 10^{6} \text { hours }
$$

Where,

$\lambda=$ component failure rate

$\lambda_{B}=$ Base failure rate of the component

$\pi_{i}=$ factors like environment, temperature, electrical stress, quality etc.

Whereas, for Integrated Circuits (IC) and Digital Circuits the failure rate $\left(\lambda_{\mathrm{p}}\right)$ is calculated by

$$
\lambda_{p}=\left(C_{1} \pi_{T}+C_{2} \pi_{E}\right) \pi_{Q} \pi_{L} \text { Failures per } 10^{6} \text { hours }
$$
where, 


\section{Reliability Assessment of Photoelectric Smoke Detector, Ionization Smoke Detector and a Fire Alarm Control Panel with Both Detectors AS Notification Device}

$\mathrm{C}_{1}=$ Complexity of IC (Eg., number of transistors)

$\mathrm{C}_{2}=\mathrm{IC}$ housing

$\pi_{T}=$ temperature conditions

$\pi_{E}=$ operational environment

$\pi_{Q}=$ quality level

It was assumed that failure rate of each electronic component, unless specified otherwise, is constant, Reliability of each component was calculated considering that its hardware are connected in series configuration. The failure rate data of alarm horn used in both the detectors was taken from [11].

A. Reliability assessment of PESD

By using Boolean laws of algebra [13],[14], the logic matrix obtained is:

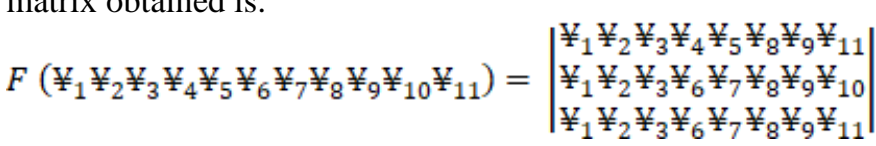

Solving it, we obtain the reliability of the photoelectric smoke detector $\mathrm{R}_{\mathrm{PESD}}$ as:

$R_{\text {PESD }}(t)=R_{1} R_{2} R_{3} R_{8} R_{9}\left[R_{4} R_{5} R_{11}+R_{6} R_{7} R_{10}+\right.$

$\left.R_{6} R_{7} R_{11}-R_{6} R_{7} R_{10} R_{11}-R_{4} R_{5} R_{6} R_{7} R_{11}\right]$

(1)

Where $\mathrm{R}_{\mathrm{i}}=\mathrm{R}_{\mathrm{i}}(\mathrm{t})=$ Reliability of component $¥_{\mathrm{i}}, i=1$ to 11 , at time ' $t$ '

\section{Consider following cases:}

(I) Failure rate of each component is constant.

Let a be constant failure rate then

$R_{P E S D}(t)=e^{-8 a t}\left[3-e^{-a t}-e^{-2 a t}\right]$

(II) Failure rate of each component is same and follows Weibull distribution

Reliability function of each component as defined below,

$R(t)=e^{-a t^{p}}$

If the failure rate of each component is 'pa', we get

$R_{P E S D}(t)=e^{-8 a t^{p}}\left[3-e^{-a t^{p}}-e^{-2 a t^{p}}\right]$

(III) Failure rate of each component is different

The calculated failure rates and respective reliabilities of various components are given in Table I. To find failure rate data for 9-volt battery, three additional assumptions were taken for calculating the same.

Assumption (i): Battery used in detectors has a lifespan of 10 years and a constant failure rate

The failure rate of 9-volt battery was calculated assuming 10 years battery life and constant failure rate as given in Table I. Substituting the reliability values of each component, in eq. (1), reliability of the system was assessed and results are given in Table IV.

Assumption (ii): Battery used in detectors has lifespan which follows Weibull Distribution and parameters have been taken from previously conducted study [15]conducted a study on the lifespan distribution of 9-volt battery (Alkaline square F77) used in smoke detectors, on the basis of data from twenty years of battery consumption and disposal in Sweden, and the lifespan distribution was found to follow a Weibull distribution with shape parameter 1.96 and scale parameter 8.11387 . For simplicity, assuming shape parameter as 2 and scale parameter as 8.114 , the calculated failure rate of battery is given in Table I. Calculating reliability function of components from failure rates given in Table I and

Substituting the same in eq.1, Reliability of the system was assessed and results are given in Table IV.

Assumption (iii): Battery lifespan follows Weibull Distribution, as per assumption (ii) above but the Test Circuit is not regularly used

The Test Circuit ( $¥_{4}$ and $¥_{5}$ ) is meant for checking whether the detector is in working condition. Assuming that the test circuit is not used regularly, reliability of system [1] reduces to:

$R_{P E S D}=R_{1} R_{2} R_{3} R_{8} R_{9}\left[R_{10}+R_{11}-R_{10} R_{11}\right]$

TABLE IV

RELIABILITY ASSESSMENT OF PESD

\begin{tabular}{|l|l|l|l|}
\hline \hline \multicolumn{1}{|c|}{ Assumption } & $\begin{array}{l}\text { Reliability } \\
R_{\text {PESD }}(t)\end{array}$ & $\begin{array}{l}\text { Failure } \\
\text { per 10 } \\
\text { Hours } \\
\left(\lambda_{\text {PESD }}\right)\end{array}$ & MTTF \\
\hline $\begin{array}{l}\text { Battery Lifespan 10 years } \\
\text { with constant failure rate }\end{array}$ & $89.2 \%$ & 13.05 & 8.74 years \\
\hline $\begin{array}{l}\text { Battery Lifespan follows } \\
\text { Weibull Distribution }\end{array}$ & $97.91 \%$ & 2.41 & 47.4 years \\
\hline $\begin{array}{l}\text { Battery Lifespan follows } \\
\text { Weibull Distribution } \\
\text { \& Test Circuit not regularly } \\
\text { used }\end{array}$ & $97.32 \%$ & 3.1 & $\begin{array}{l}36.81 \\
\text { years }\end{array}$ \\
\hline
\end{tabular}

\section{Reliability Assessment - ISD}

By using Boolean laws of algebra [13], [14], the logic matrix obtained is:

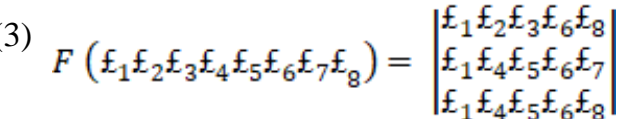

Solving it, we obtain the reliability of the photoelectric smoke detector $\mathrm{R}_{\mathrm{ISD}}$ as:

$R_{I S D}(t)=r_{1} r_{6}\left[r_{2} r_{3} r_{8}+r_{4} r_{5} r_{7}+r_{4} r_{5} r_{8}-r_{4} r_{5} r_{7} r_{8}-\right.$ $\left.r_{2} r_{3} r_{4} r_{5} r_{8}\right]$

(6)

Where $\mathrm{r}_{\mathrm{j}}=\mathrm{r}_{\mathrm{j}}(\mathrm{t})=$ Reliability of component $£_{\mathrm{j}}, j=1$ to 8 , at time ' $t$ '

Consider following cases:

(I) Failure rate of each component is constant

$R_{I S D}(t)=e^{-5 a t}\left[3-e^{-a t}-e^{-2 a t}\right]$

(II) Failure rate of each component is same and follows Weibull distribution with Reliability function of each component as defined in equation (3)

$R_{I S D}(t)=e^{-5 a t^{p}}\left[3-e^{-a t^{p}}-e^{-2 a t^{p}}\right]$ anced $T_{e}$

(8) 
Calculating reliability function of components from failure rates given in Table I and substituting the same in eq. (8), Reliability of the system was assessed and results are given in Table II.

\section{TABLE V}

RELIABILITY ASSESSMENT OF ISD

\begin{tabular}{|l|l|l|l|}
\hline \hline Assumption & $\begin{array}{l}\text { Reliability } \\
R_{I S D}(t)\end{array}$ & $\begin{array}{l}\text { Failure } \\
\text { per 106 } \\
\text { Hours } \\
\left(\lambda_{L S D}\right)\end{array}$ & $M T T F_{I S D}$ \\
\hline $\begin{array}{l}\text { Battery Lifespan 10 years with } \\
\text { constant failure rate }\end{array}$ & $90.34 \%$ & 11.60 & $\begin{array}{l}9.83 \\
\text { years }\end{array}$ \\
\hline $\begin{array}{l}\text { Battery Lifespan follows } \\
\text { Weibull Distribution }\end{array}$ & $99.72 \%$ & 0.32 & 347 years \\
\hline $\begin{array}{l}\text { Battery Lifespan follows } \\
\text { Weibull Distribution \&Test } \\
\text { Circuit not regularly used }\end{array}$ & $99.71 \%$ & 0.33 & 345 years \\
\hline
\end{tabular}

\section{A. Reliability Assessment - FACP}

By using Boolean laws of algebra [13], [14], the logic matrix obtained is:

$F\left(\mathrm{x}_{1} \mathrm{x}_{2} \mathrm{x}_{3} \mathrm{x}_{4} \mathrm{x}_{5} \mathrm{x}_{6} \mathrm{x}_{7} \mathrm{x}_{8}\right)=\left|\begin{array}{l}\mathrm{x}_{1} \mathrm{x}_{2} \mathrm{x}_{3} \mathrm{x}_{5} \mathrm{x}_{6} \\ \mathrm{x}_{1} \mathrm{x}_{2} \mathrm{x}_{3} \mathrm{x}_{5} \mathrm{x}_{7} \\ \mathrm{x}_{1} \mathrm{x}_{2} \mathrm{x}_{4} \mathrm{x}_{5} \mathrm{x}_{6} \\ \mathrm{x}_{1} \mathrm{x}_{2} \mathrm{x}_{4} \mathrm{x}_{5} \mathrm{x}_{8}\end{array}\right|$

Solving it, we obtain the reliability of the FACP as:

$$
\begin{gathered}
R_{F A C P}(t)=\eta_{1} \eta_{2} \eta_{5}\left[\eta_{3} \eta_{6}+\eta_{3} \eta_{7}+\eta_{4} \eta_{6}+\eta_{4} \eta_{8}-\right. \\
\eta_{3} \eta_{6} \eta_{7}-\eta_{3} \eta_{4} \eta_{6}-\eta_{4} \eta_{6} \eta_{8}-\eta_{3} \eta_{4} \eta_{7} \eta_{8}+ \\
\left.\eta_{3} \eta_{4} \eta_{6} \eta_{7} \eta_{8}\right] \text { (9) }
\end{gathered}
$$

where $\eta_{\mathrm{k}}(\mathrm{t})=$ Reliability of component $\mathrm{x}_{\mathrm{k}}, k=1$ to 8 , at time ' $t$ '

Consider following cases:

(I) Failure rate of each component is constant.

$R_{F A C P}(t)=e^{-5 a t}\left[4-3 e^{-a t}-e^{-2 a t}+e^{-3 a t}\right]$

(II) Failure rate of each component is same and follows Weibull distribution with Reliability function of each component as defined in equation (3)

$R_{F A C P}(t)=e^{-5 a t^{p}}\left[4-3 e^{-a t^{p}}-e^{-2 a t^{p}}+e^{-3 a t^{p}}\right]$

(III) Failure rate of each component is different and calculated as per Methodology given in MIL-HDBK-217F

The failure rates of components under states $\mathrm{x}_{2}, \mathrm{x}_{3}, \mathrm{x}_{4}, \mathrm{x}_{5}, \mathrm{x}_{6}$, $\mathrm{x}_{7}$, and $\mathrm{X}_{8}$ were calculated as per methodology of reliability estimation using MIL-HDBK-217F, as explained earlier. The calculated failure rates and respective reliabilities of various components are given in Table $\mathrm{V}$. The additional three assumptions pertaining to both detectors (PESD and ISD) viz., a constant battery lifespan of 10 years, battery lifespan following Weibull distribution [15] and tests circuits of PESD and ISD are not regularly used, were also considered. The results are shown in Table VI.

\begin{tabular}{|c|c|c|c|}
\hline Assumption & $\begin{array}{l}\text { Reliability } \\
R_{F A C P}(t)\end{array}$ & $\begin{array}{l}\text { Failure } \\
\text { per } 10^{6} \\
\text { Hours } \\
\left(\lambda_{\text {FACP }}\right)\end{array}$ & $M T T F_{\text {FACP }}$ \\
\hline $\begin{array}{l}\text { Battery Lifespan of PESD and } \\
\text { ISD is } 10 \text { years with constant } \\
\text { failure rates }\end{array}$ & $94.75 \%$ & 6.16 & 18.5 years \\
\hline $\begin{array}{l}\text { Battery Lifespan of PESD and } \\
\text { ISD follows Weibull } \\
\text { Distribution }\end{array}$ & $94.76 \%$ & 6.15 & 18.5 years \\
\hline $\begin{array}{l}\text { Battery Lifespan of PESD and } \\
\text { ISD follows Weibull } \\
\text { Distribution \& Test Circuits of }\end{array}$ & $94.75 \%$ & 6.16 & 18.5 years \\
\hline
\end{tabular}

\section{TABLE VI}

RELIABILITY ASSESSMENT OF FACP

\begin{tabular}{|l|l|l|l|}
\hline $\begin{array}{l}\text { PESD and ISD are not } \\
\text { regularly used }\end{array}$ & & & \\
\hline
\end{tabular}

RELIABILITY OF PESD, ISD AND FACP WITH INCREASE IN TIME (CONSTANT V/S WEIBULL FAILURE RATE)

A comparison between reliabilities of PESD, assuming its failure rate as 13.05 failures per $10^{6}$ hours to follow constant v/s Weibull failure rates is shown in Figure 4. The similar comparisons between reliabilities of ionization smoke detector (assumed failure rate $=11.6$ failures per $10^{6}$ hours) and FACP (assumed failure rate $=6.16$ failures per $10^{6}$ hours) are shown in Figure 5 and Figure 6 respectively.

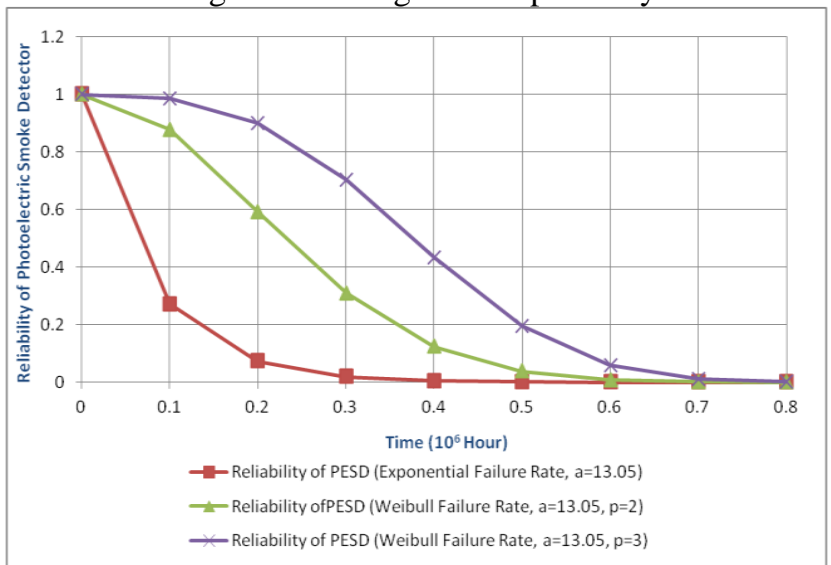

Fig. 4. Reliability of PESD with increase in time, Constant v/s Weibull failure rate distributions $\left[\lambda_{\text {PESD }}=\right.$ 13.05, $p=2 \& 3]$

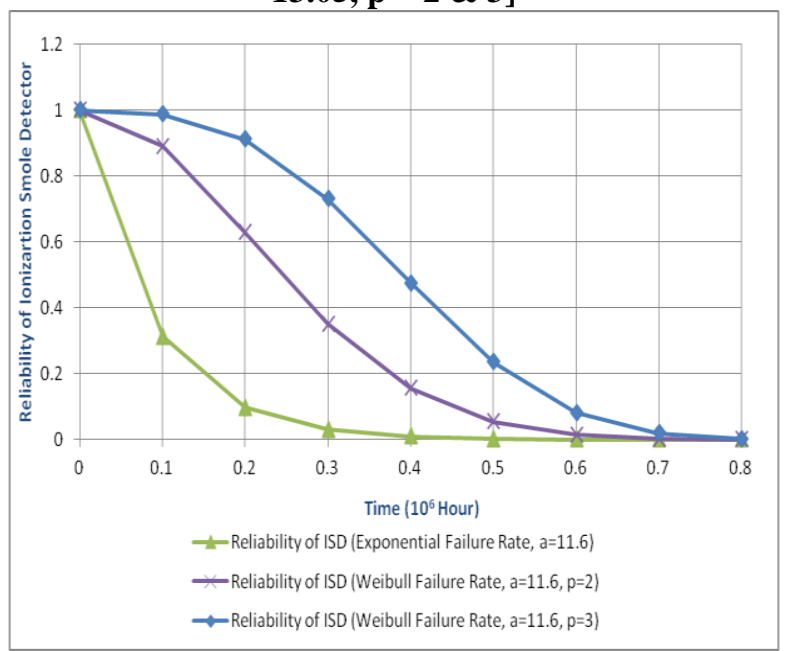

Fig. 5. Reliability of ISD with increase in time, Constant $\mathrm{v} / \mathrm{s}$ Weibull failure rate distributions $\left[\lambda_{\text {ISD }}=11.6, p=2 \&\right.$ 3] 
Reliability Assessment of Photoelectric Smoke Detector, Ionization Smoke Detector and a Fire Alarm Control Panel with Both Detectors AS Notification Device

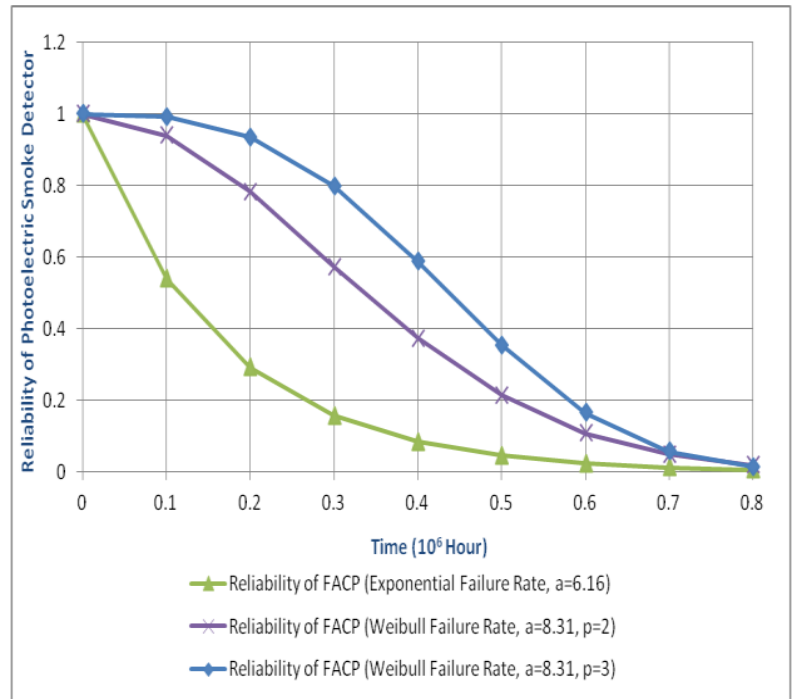

Fig. 6. Reliability of FACP with increase in time, Constant v/s Weibull failure rate distributions $\left[\lambda_{\mathrm{FACP}}=6.16, \mathrm{p}=2 \& 3\right]$

The MTTFs of PESD, ISD and FACP with increase in failure rate

Now consider the cases, in which it is assumed that each component of the system ( $¥_{\mathrm{i}}, i=1$ to $11, £_{\mathrm{j}}, j=1$ to $8, \mathrm{X}_{\mathrm{k}}, k=1$ to 8), whether PESD, ISD, or FACP, has constant failure rate ' $a$ ' and in Weibull distribution it has failure rate failure rate ' $\mathrm{pa}$ ', for $\mathrm{p}=2$ the respective MTTFs were calculated, with increase in failure rate for:

$M_{T T F_{P E D}}=44 / 360 a$

$M T T F_{P E S D}=\frac{\Gamma(1+1 / \mathrm{p})}{\mathrm{pa}^{1 / p}}\left[\frac{3}{8^{1 / p}}-\frac{1}{9^{1 / p}}-\frac{1}{10^{1 / p}}\right]$

For p $=2, M T T F_{\text {PESD }}=\frac{0.411 \Gamma(1.5]}{3 a^{1 / 2}}$

$M_{T T F} F_{I S D}=61 / 210 a$

$M T T F_{I S D}=\frac{\Gamma(1+1 / p)}{p a^{1 / p}}\left[\frac{3}{5^{1 / p}}-\frac{1}{6^{1 / p}}-\frac{1}{7^{1 / p}}\right]$

For $\mathrm{p}=2, M T T F_{I S D}=\frac{0.554 \Gamma(1.5)}{2 a^{1 / 2}}$

$M T T F_{F A C P}==237 / 840 a$

$M_{T T F_{F A C P}}=\frac{\Gamma(1+1 / p)}{p a^{1 / p}}\left[\frac{4}{5^{1 / p}}-\frac{3}{6^{1 / p}}-\frac{1}{7^{1 / p}}+\frac{1}{8^{1 / p}}\right]$

For p $=2, M T T F_{\text {FACP }}=\frac{0.537 \Gamma(1.5)}{2 a^{1 / 2}}$

The comparisons of MTTF under constant and Weibull failure rate are shown in Table VII (PESD), Table VIII (ISD) \& Table IX (FACP) respectively.

\section{Table VII}

MTTF OF PESD WITH INCREASE IN FAILURE RATE, CONSTANT V/S WEIBULL FAILURE RATE DISTRIBUTIONS

\begin{tabular}{|c|c|c|}
\hline \multirow{2}{*}{$\begin{array}{l}\text { Failure Rate } \\
\text { per } 10^{6} \text { hour }\end{array}$} & \multicolumn{2}{|c|}{ MTTF $_{\text {PESD }}$ (in Years) } \\
\hline & $\begin{array}{c}\text { Constant } \\
\text { Failure Rate }\end{array}$ & $\begin{array}{l}\text { Weibull Failure } \\
\text { Rate }(\mathrm{p}=2)\end{array}$ \\
\hline 0.5 & 27.9 & 41.69 \\
\hline 1 & 13.95 & 29.48 \\
\hline 1.5 & 9.3 & 24.07 \\
\hline 1.597 & 8.74 & - \\
\hline 2 & 6.98 & 20.85 \\
\hline 2.5 & 5.58 & 18.65 \\
\hline 3 & 4.65 & 17.02 \\
\hline 3.5 & 3.99 & 15.76 \\
\hline 4 & 3.49 & 14.74 \\
\hline- & - & - \\
\hline- & - & - \\
\hline
\end{tabular}

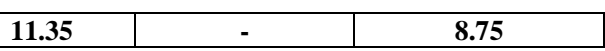

TABLE VIII

MTTF OF ISD WITH INCREASE IN FAILURE RATE, CONSTANT V/S WEIBULL FAILURE RATE DISTRIBUTIONS

\begin{tabular}{|c|c|c|}
\hline \multirow[b]{2}{*}{$\begin{array}{l}\text { Failure Rate } \\
\text { per } 10^{6} \text { hour }\end{array}$} & \multicolumn{2}{|c|}{ MTTF $_{\text {ISD }}$ (in Years) } \\
\hline & $\begin{array}{c}\text { Constant } \\
\text { Failure Rate }\end{array}$ & $\begin{array}{l}\text { Weibull Failure } \\
\text { Rate }(\mathrm{p}=2)\end{array}$ \\
\hline 0.5 & 66.32 & 56.05 \\
\hline 1 & 33.16 & 39.63 \\
\hline 1.5 & 22.11 & 32.36 \\
\hline 2 & 16.58 & 28.02 \\
\hline 2.5 & 13.26 & 25.06 \\
\hline 3 & 11.05 & 22.88 \\
\hline 3.375 & 9.83 & - \\
\hline 3.5 & 9.47 & 21.18 \\
\hline 4 & 8.29 & 19.82 \\
\hline- & - & - \\
\hline- & - & - \\
\hline 16.25 & - & 9.83 \\
\hline
\end{tabular}

TABLE IX

MTTF OF FACP WITH INCREASE IN FAILURE RATE, CONSTANT V/S WEIBULL FAILURE RATE DISTRIBUTIONS

\begin{tabular}{|c|c|c|}
\hline \hline \multirow{2}{*}{$\begin{array}{c}\text { Failure Rate } \\
\text { per } 10^{6} \text { hour }\end{array}$} & \multicolumn{2}{|c|}{ MTTF $_{\mathrm{FACP}}$ (in Years) } \\
\cline { 2 - 3 } & $\begin{array}{c}\text { Constant } \\
\text { Failure Rate }\end{array}$ & $\begin{array}{l}\text { Weibull Failure } \\
\text { Rate }(\mathrm{p}=2)\end{array}$ \\
\hline 0.5 & 64.42 & 38.84 \\
\hline 1 & 32.21 & 27.47 \\
\hline 1.5 & 21.47 & 22.43 \\
\hline $\mathbf{1 . 7 4}$ & $\mathbf{1 8 . 5 1}$ & - \\
\hline 2 & 16.1 & 19.42 \\
\hline 2.5 & 12.88 & 17.37 \\
\hline $\mathbf{2 . 2}$ & - & $\mathbf{1 8 . 5 2}$ \\
\hline 3 & 10.74 & 15.86 \\
\hline 4 & 9.2 & 14.68 \\
\hline
\end{tabular}

TABLE X

FAILURE RATES (PER $10^{6}$ HOURS) OF PESD, ISD AND FACP

COMPONENTS QUALITY FACTORS - "MILITARY SPECIFIC"(MIL) AND "LOWER THAN MILITARY SPECIFIC"(LOW)

\begin{tabular}{|c|c|c|c|c|c|c|}
\hline $\begin{array}{l}\text { Assumptions } \\
\rightarrow\end{array}$ & \multicolumn{2}{|c|}{$\begin{array}{l}\text { Detectors Battery } \\
\text { Life is } 10 \text { years } \\
\text { Follows } \\
\text { Exponential } \\
\text { Distribution }\end{array}$} & \multicolumn{2}{|c|}{$\begin{array}{l}\text { Detector } \\
\text { Battery Life } \\
\text { Follows } \\
\text { Weibull } \\
\text { Distribution }\end{array}$} & \multicolumn{2}{|c|}{$\begin{array}{l}\text { Detector Battery } \\
\text { Life Follows } \\
\text { Weibull } \\
\text { Distribution. } \\
\text { Test Circuit is not } \\
\text { used }\end{array}$} \\
\hline Quality $\rightarrow$ & \multirow[t]{2}{*}{ MIL } & \multirow[t]{2}{*}{ LOW } & \multirow[t]{2}{*}{ MIL } & \multirow{2}{*}{$\begin{array}{c}\mathrm{LO} \\
\mathrm{W}\end{array}$} & \multirow[t]{2}{*}{ MIL } & \multirow[t]{2}{*}{ LOW } \\
\hline System $\downarrow$ & & & & & & \\
\hline$\lambda_{\text {PESD }}=$ & 12.34 & 13.05 & 0.93 & 2.41 & 0.98 & 3.1 \\
\hline$\lambda_{\text {ISD }}=$ & 11.50 & 11.60 & 0.09 & 0.32 & 0.09 & 0.33 \\
\hline$\lambda_{\text {FACP }}=$ & 6.03 & 6.16 & 6.03 & 6.15 & 6.03 & 6.16 \\
\hline
\end{tabular}

\section{SUMMARY AND CONCLUSION}

The reliability of PESD was found to be ranging from $89.2 \%$ to $97.32 \%$ under various assumptions mentioned in Table IV. The reliability of ISD was found to be higher, ranging from $90.34 \%$ to $99.71 \%$ under similar assumptions (Table V). Whereas reliability of FACP remains unaffected by these variations in reliability of notification device, which may be attributed to presence of end line Resistor in the circuit. These comparisons indicates that when we apply constant failure rate reliabilities of PESD, ISD and FACP drops significantly with respect to time. 
Whereas in weibull distribution reliability of all three system is comparatively consistent with respect to time.

The failure rate (failures per $10^{6}$ hours) for PESD was ranging from 0.98 to 12.34 while that of ISD was found to be lower, ranging from 0.09 to 11.50 under assumptions as mentioned in Table $\mathrm{X}$.

The failure rate for PESD, considering battery life to be Weibull distributed was 2.41 with test circuit and was 3.1 failures per $10^{6}$ hours without test circuit. It is consistent with the failure rate data of PESD given in OREDA handbook .

PESD and ISD are parts of the notification device component of FACP. However, different values of their failure rates as given in Table II, IV does not adversely affect failure rate and reliability of FACP (Table VI \& X). It may be attributed to presence of End of Line Resistor component of FACP (Table V) that regularly checks the circuit for problems in notification device.

A comparison between failure rates of PESD, ISD and FACP, calculated on the basis of two quality factors of electronic components - military specific and lower than military specific (Table $\mathrm{X}$ ) shows that lower quality factor results in considerable increase in failure rates of PESD as compared to ISD and FACP.

Assuming average battery lifespan to be 10 years with constant failure rate, the MTTF of both the fire detectors comes out to be between 8.74 years to 9.83 years (Table III and Table VIII)

Considering MTTF values of PESD, ISD and FACP to be 8.74 years, 9.83 years and 18.51 years respectively and using Table VII, VIII, IX viz., the comparison tables of MTTFs of PESD, ISD and FACP with increase in failure rate, it can be assessed that:

(i) MTTF of PESD is 8.74 years if its each component $\left(¥_{i}\right.$, $i=1$ to 11 ) has constant failure rate 1.597 and 11.35 with Weibull failure rate distribution

(ii) MTTF value of ISD is 9.83 years if its each component $\left(£_{\mathrm{j}}, j=1\right.$ to 8$)$, has constant failure rate 3.375 and 16.25 with Weibull failure rate distribution

(iii) MTTF value of FACP is 18.51 years if its each component ( $\mathrm{x}_{\mathrm{k}}, k=1$ to 8 ) has constant failure rate 1.74 and 2.2 with Weibull failure rate distribution.

which is consistent with the requirements of National Fire Protection Association, USA [18] to replace smoke alarms at least every 10 years.

\section{REFERENCES}

1. R.W. Bukowski, E.K. Budnick and C.F. Schemel, "Estimates of the Operational Reliability of Fire Protection Systems." in Conference on Fire Research and Engineering (ICFRE3) Proceedings. Natinal Institute of Standards and Technology, International Association of Fire Safety Science (IAFSS), Chicago. 1999, pp. 87-98.

2. N.K. Fong, "Reliability study on sprinkler system to be installed in Old high-rise buildings". International Journal on Engineering Performance-Based Fire Codes, vol. 2, no. 2, pp. 61-67, 2000

3. Y. Chen, "Reliability Analysis of a Fire Alarm System". Procedia Engineering vol. 24, pp. 731 - 736, 2011

4. OREDA, “OREDA Reliability Data”. OREDA Participants, Available from: Det Norske Veritas, NO 1322 Høvik, Norway, 4rd edition, 2002

5. B. Forell, J. Peschke, S. Einarsson, M. Röwekamp. "Technical reliability of active fire protection features - generic database derived from German nuclear power plants". Reliability Engineering and System Safety. vol. 145, pp. 277-286, Sept. 2015

6. MILHDBK-217F "Military Handbook Reliability Prediction of Electronic Equipment”, US Department of Defence, USA, Dec.1991

7. P. Lall, "Tutorial: Temperature as an input to Microelectronics-Reliability Models". IEEE Transactions on Reliability. vol. 45, no. 1, pp. 3-9, March 1996
8. E. De Francesco, R. De Francesco and E. Petritoli, "Obsolescence of the MIL-HDBK-217: A critical review," IEEE International Workshop on Metrology for AeroSpace (MetroAeroSpace), Padua, pp. 282-286, 2017

9. K. C. Potdukhe, A. P. Munshi and A. A. Munshi, "Reliability prediction of new improved current source inverter (CSI) topology for transformer-less grid connected solar system," IEEE Power, Communication and Information Technology Conference (PCITC), Bhubaneswar, 2015, pp. 373-378, 2015

10. R.W. Bukowski, E.K. Budnick and C.F. Schemel, "Estimates of the Operational Reliability of Fire Protection Systems." in Conference on Fire Research and Engineering (ICFRE3) Proceedings. Natinal Institute of Standards and Technology, International Association of Fire Safety Science (IAFSS), Chicago. 1999, pp. 87-98.

11. N.K. Fong, "Reliability study on sprinkler system to be installed in Old high-rise buildings". International Journal on Engineering Performance-Based Fire Codes, vol. 2, no. 2, pp. 61-67, 2000

12. Y. Chen, "Reliability Analysis of a Fire Alarm System". Procedia Engineering vol. 24, pp. 731 - 736, 2011

13. OREDA, "OREDA Reliability Data”. OREDA Participants, Available from: Det Norske Veritas, NO 1322 Høvik, Norway, 4rd edition, 2002

14. B. Forell, J. Peschke, S. Einarsson, M. Röwekamp. "Technical reliability of active fire protection features - generic database derived from German nuclear power plants". Reliability Engineering and System Safety. vol. 145, pp. 277-286, Sept. 2015

15. MILHDBK-217F "Military Handbook Reliability Prediction of Electronic Equipment", US Department of Defence, USA, Dec.1991

16. P. Lall, "Tutorial: Temperature as an input to Microelectronics-Reliability Models". IEEE Transactions on Reliability. vol. 45, no. 1, pp. 3-9, March 1996

17. E. De Francesco, R. De Francesco and E. Petritoli, "Obsolescence of the MIL-HDBK-217: A critical review," IEEE International Workshop on Metrology for AeroSpace (MetroAeroSpace), Padua, pp. 282-286, 2017

18. K. C. Potdukhe, A. P. Munshi and A. A. Munshi, "Reliability prediction of new improved current source inverter (CSI) topology for transformer-less grid connected solar system," IEEE Power, Communication and Information Technology Conference (PCITC), Bhubaneswar, 2015, pp. 373-378, 2015

19. M. Ghavami and C. Singh, "Reliability evaluation of electric vehicle charging systems including the impact of repair," IEEE Industry Applications Society Annual Meeting, Cincinnati, OH, 2017, pp. 1-9, 2017

20. A.E. Cote, Operation of Fire protection Systems. National Fire Protection Association, Quincy, Massachusett, 2003 pp. 1 - 671

21. Photoelectric smoke detector with I/C and I/O. NXP Semiconductors. https://www.nxp.com/docs/en/data-sheet/MC145010.pdf

22. P.P. Gupta and R.K. Sharma, "Reliability behaviour of a power plant by boolean function technique under arbitrary failure time distribution". Microelectronics Reliability. vol. 26, no. 5, pp. 815-819, 1986

23. Y.V.S Sarma, H.P. Hines, "Reliability Analysis of a Complex System Using Boolean Function Technique." in Beckmann M.J., Gopalan M.N., Subramanian R. (eds) Stochastic Processes and their Applications. Lecture Notes in Economics and Mathematical Systems, vol. 370. Springer, Berlin, Heidelberg, 1991

24. Y. Kalmykova, P.E-O. Berg, João Patrício and V Lisovskaja. "Portable battery lifespan and new estimation method for battery collection rate based on a lifespan modeling approach". Resources, Conservation and Recycling. vol. 120, pp. 65-74. 2017

25. A. Birolini, Reliability Engineering. Theory and Practice. Third Edition. Springer-Verlag Berlin Heidelberg. 1999, pp. 1 - 495

26. Low-Power CMOS Ionization Smoke Detector IC with Temporal Pattern Horn Driver. NXP Semiconductors. https://www.nxp.com/docs/en/data-sheet/MC145017.pdf

27. NFPA 72 Code, National Fire Protection Association, USA https://www.nfpa.org/News-and-Research/News-and-media/Press-Ro om/News-releases/2016/NFPA-announces-2016-FPW-theme 


\section{Reliability Assessment of Photoelectric Smoke Detector, Ionization Smoke Detector and a Fire Alarm Control Panel with Both Detectors AS Notification Device AUTHORS FROFILE}

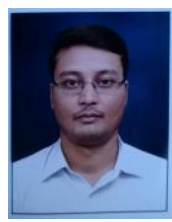

Anil Chandra is a Ph.D. scholar at Amity Institute of Applied Sciences, Amity University Uttar Pradesh. He is working in the area of "Reliability Modeling". He did his B.Sc. $(\mathrm{H})$ degree in Mathematics from University of Delhi (India) and M.Sc. Mathematics degree from Himachal Pradesh University (India).

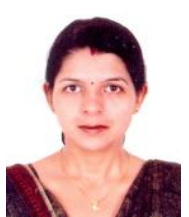

Dr. Surbhi Gupta is serving as Assistant Professor in Mathematics Department at Amity Institute of Applied Sciences, Amity University Uttar Pradesh, Noida, India. She has fifteen years experience of teaching B.Sc. and M.Sc. students. She has published one book and nine research papers. She has delivered invited talks in various conferences. She is a life member of ISIAM and IAENG. She has published Research papers in various international journals and guided Ph.D students for their research projects. Her main research work focuses on Reliability Modeling.

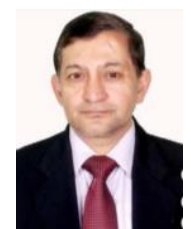

Prof. (Dr.) Chandra K. Jaggi is serving as a Professor at the Department of Operational Research, University of Delhi, Delhi, India. He has guided $12 \mathrm{PhD}$ and 21 MPhil candidates in Operations Research. He has published 7 book chapters and also papers in several national and international journals. He is also a reviewer of many international/national journals. He is Ex-Editor-in-Chief of IJICM and Associate Editor of IJSAEM, Springer, Co-Editor / Reviewer-In-Charge of The Gstf JMSOR and on the Editorial Board of the IJSS: Operations \& Logistics, IJSOI, AJOR, IJECBS, JASR, AJBAS. He was awarded Certificate in 2009 for his Significant Contributions in Operation Management by The Society of Reliability Engineering, Quality and Operations Management, New Delhi. He was awarded Shiksha Rattan Puraskar (for Meritorious Services, Outstanding Performance and Remarkable Role) in 2007 by India International Friendship Society. He has traveled extensively in India and abroad and delivered invited talks. He is Life Member of Operational Research Society of India, Indian Science Congress Association, and Fellow Member of International Science Congress Association, Computer Society of India, The Society of Mathematical Sciences, University of Delhi, India, Society for Reliability Engineering, Quality and Operations Management, Indian Society for Probability and Statistics. 